QIJIS: Qudus International Journal of Islamic Studies

Volume 6, Issue 2, Agustus 2018

\title{
MUHAMMAD ABDUH'S THOUGHT ON MUHAMMADIYAH EDUCATIONAL MODERNISM: Tracing The Influence in Its Early Development
}

\author{
Muslich Shabir \\ Walisongo State Islamic University \\ muslich_shabir@walisongo.ac.id \\ Sulistiyono Susilo \\ Institute of Social Sciences and Cultural Studies \\ sulistiyonosusilo@gmail.com
}

\begin{abstract}
This article originally attempts to particularly find an answer whether the Muslim educational reforms introduced by the Muhammadiyah movement in Indonesia were influenced by the ideas of 'Abduh. This study was conducted through collecting materials, documents and books written in English, Indonesian and Arabic to assess and analyse the traces of the influence of Muhammad 'Abduh's ideas on Muhammadiyah in terms of Muslim educational reform. The results revealed the Muhammadiyah's educational reform programs were to a significant extent influenced by 'Abduh and founded on ideas which were undeniably similar to the ideas of 'Abduh. This suggests that the reform shows traces of a probable but unquantifiable influence of 'Abduh and that this reform is certainly, at the very least, a reflection of 'Abduh's pervasive influence throughout the larger world of Islam.
\end{abstract}

Keywords: Muhammad 'Abduh, the Muhammadiyah, Educational Reform. 


\section{A. Introduction}

Muhammad 'Abduh (1849-1905) was one of the most prominent leaders of Islamic reform whose writings and ideas spread widely in the Muslim world, notably in Egypt, Bahrain, Singapore, Russia, Tunisia, Algeria, Java (Indonesia), Tabriz (Iran), Beirut (Libanon), Tripoli (Libya), Homs (Syria), Bombay (India), and Europe (Rida, 1324 AH: 284-298). 'Abduh ideas on Islamic reform seem to have influenced Islamic thinking even in far-away Indonesia where in the early twentieth century several Islamic reform movements were established, such as Jami'at Khair (Association for the Good, 1905), Persyarikatan Ulama (Union of Muslim Scholars, 1911), Muhammadiyah (1912), al- Irsyad (The Guidance, 1913) and Persatuan Islam (Unity of Islam, 1923) (further discussion of the origin of Islamic reform movements in early twentieth century Indonesia, see: Federspiel, 1970; Nakamura, 2012; Azra, 2004; Saleh, 2001). Of these, the most significant one, since pre-World War II until the present time, has been the Muhammadiyah(Noer, 1973). Sukarno, the first President of the Republic of Indonesia, who was in office from 1945-1966, was a chairman of the Board of Education of the Provincial-leadership of Bengkulu in 1938 when he was exiled by the Dutch. The second president, General Suharto, studied in Muhammadiyah's Schakelschool (Dutch language elementary school) and was a member of Hizbul Watan (Muhammadiyah's boyscout)(Puar, 1989). Both Muhammad 'Abduh and the Muhammadiyah touched on several fields of Islamic reform in the forms of religious, educational and social aspects.

This article focuses on only one aspect of their ideas and programs namely on educational reform and attempts to find the answer to whether the Muslim educational reforms introduced by the Muhammadiyah movement in Indonesia were influenced by the ideas of Muhammad 'Abduh.. Scholars such as Charles C. Adams(1968), John L. Esposito (1988), M. A. Zaki Badawi (1978), and Uthman Amin (1953; 1965)have taken the view that Muhammad 'Abduh's ideas influenced the establishment 
of Islamic reform movements in the Muslim world in terms of purification of Islamic faith, reformation of Muslim education and modernization of social being. On the other hand, since its very beginning the Muhammadiyah's main purposes have been to instill the true teachings of the Qur'an and the sunnah of the Prophet Muhammad; to eliminate idolatrous beliefs and cults, superstitious practice and unreasonable customs among Muslim community;to advance social, political and economic conditions among the Indonesians in general and the Muslims in particular; and to enable Islamic educational institutions to meet the need for modern development. (Susilo \& Syato, 2016; Alatas, 1986; Kamal\& Sholeh, 1988; Puar, 1989; Ali, 1985; Salam, 1965; The Department of Information of the Republic of Indonesia, n.d; Landon, 1947; Madmarn, 1990). Because of these similarities, some regard the Muhammadiyah's programs as being influenced by the ideas of 'Abduh. Surprisingly, none of them, to the best of our knowledge, arguably reveals specifically detailed discussion on the point of reflection of 'Abduh's ideas on the Muhammadiyah, especially in the matter of Muslim educational reform. Likewise, all of the writings as well as other materials on the Muhammadiyah concentrate primarily on the background, objectives, development and activities of the movement.

This study was conducted through collecting materials, documents and books written in English, Indonesian and Arabic in which those above-mentioned are considerably valuable to assess and analyse the traces of the influence of Muhammad 'Abduh's ideas on the Muhammadiyah in the matter of Muslim educational reform. This article begins with an introduction, followed the main thrust of this study of 'Abduh and his ideas on Islamic reform that deals with the question of his influence on the educational reform of the Muhammadiyah movement in Indonesia. This part proceeds in four steps. First, it describes the educational systems that existed in Egypt in the time of Muhammad 'Abduh. Second, it draws educational system in Indonesia in the time of the establishment of the Muhammadiyah. Third section discusses 
the Muhammadiyah's ideas and programs relating to Muslim educational reform. Fourth, it examines the certain parallels between the ideas of 'Abduh and those of the Muhammadiyah in terms of Muslim educational reform. Finally, this article concludes the influence of 'Abduh on the Muhammadiyah.

\section{B. Discussion}

\section{Abduh and Muhammadiyah in Academic Circles}

Before the authors elaborate on the two subjects of Muhammad 'Abduh and the Muhammadiyah, it is appropriate at this point to review what some scholars have written about these subjects. The most extensive record of Muhammad 'Abduh's life and work is Tarīkh al-Ustādh al-Imām al-Shaykh Muhammad 'Abduh (Ridha, 1324; 1344; 1350 AH), and Al-Manār (Rida, 1327 AH)written by Muhammad Rashid Rida and consisting of three volumes. The book Muhammad Abduh by Uthman Amin(1953), which was translated from Arabic into English by Charles Wendell, is another important source on 'Abduh's life. Among Western authors, Charles C. Adams, in his book Islam and Modernism in Egypt (Adams, 1968), provides a detailed biography of Muhammad 'Abduh and account of his doctrines. It also deals with 'Abduh's colleague, al-Sayyid Jamal al-Din al-Afghani (1839-97), and Muhammad Rashid Rida (1865-1935), one of 'Abduh's prominent disciples, and the "Manār" party as well as the younger Egyptian modernists. Also, Arabic Thought in the Liberal Age: 1798-1939 by Albert Hourani (1955) is a significant source, especially the chapters entitled "Muhammad 'Abduh" and "Abduh's Egyptian Disciples: Islam and Modern Civilization."

As for the Muhammadiyah, James L. Peacock (1978), in his book Purifying the Faith: the Muhammadiyah Movement in Indonesia, discusses the movement in general. Peacock had observed a Muhammadiyah training camp named "Darul Arqam" while in Indonesia. In addition, Leslie H. Palmer (1954) and Howard M. Federspiel (1970) provide insightful overview 
of the role of the Muhammadiyah movement after Indonesian independence. Among the works published in Indonesia, major consideration must be given to Muhammadijah dan Kebangunan Islam di Indonesia (Muhammadiyah and Islamic Resurgence in Indonesia) by Solichin Salam (1965). Other Indonesian authors who wrote about the movement are A. Jainuri (1981)in his book Muhammadiyah: Gerakan Reformasi Islam di Jawa Pada Awal Abad Kedua Puluh (Muhammadiyah: An Islamic Reform Movement in Java in the Early of the Twentieth Century), and Yusuf Abdullah Puar (1989), with his book Perjuangan dan Pengabdian Muhammadiyah (The Muhammadiyah Struggle and Service). It is also important to mention a book written by Arbiyah Lubis (1993),Pemikiran Muhammadiyah dan Muhammad Abduh: Suatu Studi Perbandingan (Thought of Muhammadiyah and Muhammad Abduh: A Comparative Study). This book compares the thoughts of Muhammadiyah with Muhammad Abduh in three aspectsof theology, sharī'a and education. Lubis does not specifically analyze the influence of Muhammad Abduh's thought on Muhammadiyah in educational aspect.

\section{Muhammad 'Abduh's Ideas on Muslim Educational Reform}

This section briefly describes the historical condition of education in Egypt in the time of Muhammad 'Abduh that motivated him to reform the Muslim educational system. Until the French occupation in 1798, in general, there was a single system of education in Egypt called kuttāb. In the kuttāb, the children learned the Qur'an, recited prayers, read, and wrote Arabic.. If they wanted to continue their studies, they enrolled in al-Azhar (Heyworth-Dunne, 1968). Students in al-Azhar were divided according to their place of origin into various riwāqs (hostels). Each student studied there under the guidance of the teachers of his riwāq until he reached a sufficently advanced stage to choose teachers from outside his riwāq and madhhab (Heyworth-Dunne, 1968). The teacher would sit at the foot of a particular pillar and 
give lessons to a circle (halqah) of students, based upon the text of some author who was regarded as an authority. The teachers spent years pouring over the commentaries (sharh, pl. shurūh) on texts, explanatory notes (hāshiyah, pl. ḥawāsh) and glosses (ta'līq, pl. ta līqāt or taqrīr, pl. taqārīr) on the commentaries. It was up to the students to memorize what they were reading. The usual course of study lasted for about eight or ten years, though some students stayed for only two or three years. There were no examination nor attendance policies. The subjects studied in alAzhar were limited to the religious sciences and those regarded ancillary to these sciences, such as Arabic and astronomy. No secular science was taught there (Heyworth-Dunne, 1968; Amin, 1953; Dodge, 1961). This is one type of educational system that existed in Egypt and the other was the system inspired by the European model. The coming of the French brought the Egyptians into contact with Western civilization. The French authorities established schools for the children of French parents (HeyworthDunne, 1968). Six years following the French occupation, in 1805, Muhammad 'Ali rose to power. It was he who seriously opened Egypt up to French ways and influence. He wanted to modernize Egypt, but his greatest obstacle was the lack of qualified men. Therefore, in 1809 he began sending missions of students to European countries, especially Italy, French and England, in order to study military science, shipbuilding, management of ships, printing, mechanics and engineering. In 1816, Muhammad Ali began opening schools based on the European model; he did not create a national educational system (Heyworth-Dunne, 1968). The Khedives after him maintained the European model and ignored the religious subjects; or if they were taught, it was to a very limited extent, except for Dār al-'Ulūm, which was opened in 1872 by the Khedive Isma il Pasha(Adams, 1968). Not all of the teachers of those schools were Muslims; some of them were Europeans.

Therefore, Abduh witnessed an educational system in Egypt that was in reality a juxtaposition of two entirely different 
systems; one of them comprised the old religious schools with al- Azhar at their apex, and the other comprised the modern schools. These two systems of education had no relation with each other, and neither was satisfactory in itself. Consequently, these systems produced two different educated classes in Egypt, each with a spirit of its own. Thosewho graduated from the religious schools resisted all change, as a result of traditional education which suffered from stagnation and slavish imitation, and lacked the sciences necessary for living in the modern world. On the other hand, thosewho were educated in the modern schools accepted change and embraced a wide range of ideas from modernEurope (Hourani, 1970; Ahmed, 1960). `Abduh was very concerned with the condition of Muslim education. He had an idea that the essential purpose of Muslim education is to nurture minds and souls and to raise persons to a level where they would become capable of achieving full happiness, or as much of it as possible, in this life and the life beyond. There are two pillars in education, that are the intellectual and the spiritual. Intellectual education seeks to bring minds out of simplicity and ignorance and away from false concepts and ideologies so that they might acquire correct knowledge and valid concepts. As a result of this endeavor, minds become capable of distinguishing between the good and the bad, between what is harmful and what is useful. This viewpoint becomes embedded in people's character. The truly brilliant mind is the one that is most effective in distinguishing the good from the bad. Spiritual education seeks to create excellent qualities and sensibilities in the soul and to refine it, keeping it away from corrupting influences so that the person who has such qualities and sensibilities will grow up in accordance with the rules and requisites of human society and become habituated to them ('Imarah, 1972).

He also campaigned for the necessity of the modernsciences; he considered that they were very important as a means whereby the Muslims would gain happiness in their worldly life; as he said, 
"There is no religion without a state; no state without authority; no authority without power; and no power without wealth. The state does not possess trade or industry; its wealth is the wealth of its people. The people's wealth is not possible without the spread of those sciences amongst them so that they know the ways for acquiring wealth."(Rida, $1344 \mathrm{AH}$ : 43).

'Abduh's ideas and programs concerning educational reforms can be distinguished into three distinct periods: his pre-exile period ending in 1882, his activities during his exile ending in 1888, and the period after his return until his death in 1905. During the first period, after meeting with al-Afghani, he recognized most clearly the shortcomings of an al-Azhar education (for general description about al-Azhar see. Houtsma et al., 1987). He called for the introduction of modernsciences into al-Azhar and teaching methods. When he was appointed teacher in al-Azhar, Dār al-'Ulūm and the Khedivial School of Language, he made every endeavor to revise the methods of teaching, while emphasizing the importance of reform. As a basis of his lectures on political science in al-Azhar, he used the book of The History of Civilization in Europe and in France by Guizot. In his teaching he kept before him as his objective the raising of a new generation who would become concerned with the revival of the Arabic language and the Islamic sciences and would be trained in selfgovernment(Adams, 1968). His serious concern over education was reflected also in his articles which appeared in al-Waqā'i alMiSriyyah (The Egyptian Events), of which he was chief editor. From the beginning he concerned himself with education and campaigned against the educational policy of the day. Through his writings, he frequently criticized the schools, teachers, methods of instruction, and general conduct of the educational program. The second period is when he was in exile, especially in Beirut from 1885-1888. As when he was in Egypt, he opened his house in Beirut for scholars, students and men of literary tastes from all sects and religious communities; i.e., Sunnis, Shi'ites, Druses, Christians and Jews. At the end of 1885 he was invited to teach at the Sultaniyyah school. He introduced improvements into the 
administration of the school and the methods of instruction. He also introduced courses in theology, jurisprudence and history into the curriculum (Adams, 1968). He became more concerned with the praxis of education than he had been in Egypt, when he was concerned mainly with generalities. In a speech he gave at the Sultaniyyah school, he emphasized that the Muslims needed to learn a science beyond the practical sciences of industry, agriculture and commerce which the people felt in need of; rather, the science needed was a science touching the soul, a science of human life which was founded in religion, so that the Muslims would gain a deeper understanding of their religion (Rida, $1344 \mathrm{AH})$.

During his stay in Beirut, he also wrote two detailed papers advocating reform; one to the Shaykh al-Islam in Constantinople (in 1887) on the reform of religious education; and the other to the Governor of Beirut on the educational reform of Syria, suggesting that the Governor provide proper education for each of the various groups existing in Beirut (the Muslim Sunni and Shi'i, the Druze, the Nusayriyyah, and Christians; i.e., Maronite, Catholic, Orthodox and Protestant) to ensure their loyalty to the government. In his letter to the Shaykh al-Islam, he indicated the lack of an integrated educational system in both religious and government schools. He proposed that religious education for Muslims should be divided into three categories. The first iseducation for the general public, consisting of artisan, tradesman and agricultural worker. The second iseducation for the politician, military, judge and administrator, while the third iseducation for the 'ulamā' whose concern is the guidance and education. The first category would embrace the basics of writing, reading, arithmetic as well as simple instruction on Islamic faith, Islamic law, ethics and Islamic history. Similar subjects would be included in the second category, but would be taught more intensively, while introductory books on logic, principles of scientific theory and the methods of debate would be used. The third category would embrace tafsir of the Qur'an, various branches of Arabic, hadīth, ethics, uṣūl al-fiqh, 
Islamic history, methods of public speaking and debate, theology, and the differences among Islamic schools of law. All instruction would be aimed at establishing the position of religion so deeply in the heart of the students that it would direct their every action, thus uniting them spiritually and materially in the service of Islam('Imarah, 1972). The third period of 'Abduh's career, as an educational thinker and reformer, came after his return to Egypt from 1888 until 1905. Like his efforts in Beirut, he suggested to the government a system of education tookits basis from Islam. He criticized the "Westernizers" in Egypt who adopted Western education and sciences without any reference to the cultural milieu of the Muslims, and did not base their educational institutions on Islam. It meant that they disseminated seeds which were not appropriate for the education of the coming generation. The aim of the schools was to provide training chiefly for civil service and government employment. Those secular schools which were established since the era of Khedive Muhammad 'Ali until the time of 'Abduh had failed to achieve much in the way of personal training or character-building. The products of these schools worsened despite their greater knowledge.Since their general knowledge and demeanor were not based on the principles of their religion, there was no refinement of their souls ('Imarah, 1972). Another objective of 'Abduh's educational reform was the reform of his former alma mater, al-Azhar. He and his friend, 'Abd al-Karim Sulaiman, were made members of this Council. Its work was both academic and administrative; it attempted not only to improve conditions of work and discipline among the students and to organize the finances and establish a central library, but also to change the curriculum with the introduction of newly recommended texts. More emphasis was to be placed on understanding the texts and less on memorizing them, and more time was to be given to substantive subjects (ulūm al-maqāsid) such as tauhīd, tafsīr, hadīth, fiqh, usūl al-fiqh and akhlāq than to the "means of study" (ulūm al-wasā'il) such as mantīq, nạ̣w, ș arf, balāghah and murșalah al-hadīth as well as arithmetic and 
algebra. He recommended that a few modernsubjects, such as history, physical sciences, geography, philosophy and sociology should be included in al-Azhar curriculum (Amin, 1965).

'Abduh did not succeed in executing all of these proposals, for he faced two major obstacles. The first was fromagroup of conservative shaykhs who flatly rejected the idea of reform and accused 'Abduh of secularizing the Islamic institution. The second was from the Khedive 'Abbas who had a misunderstanding with 'Abduh on the property of awqāf (plural of waqf, meaning "endowments"). 'Abduh, in his capacity as a member of the Awqāf Council, refused to allow the Khedive to exchange a part of the awqāf lands in al-Jizah, which was prepared for building, with the Khedive's cultivated land. In revenge, the Khedive encouraged the group of conservative shaykhs to criticize 'Abduh and ignore his ideas of reform(al-'Adawi, n.d). `Abduh was hopelessly fighting against the brick-wall of the traditionalist and conservative shaykhs and was very disappointed. Shortly before his death, on a day in March, 1905, an English journalist, Harold Spender, came to al-Azhar to visit `Abduh and found him sitting alone in his little room. 'Abduh said to the journalist,

"Here I am, all alone, just as you see me. Not one of the professors will help me; not one of those who preach benevolence will come to my aid. I want to teach something useful in this university, as a change from these decayed old commentaries which have become empty of all meaning, and more harmful even than your old books written in the Middle Ages."

"..... But do I find anyone to assist me in such a work? And if I find no one, can I succeed by myself?." (Amin, 1965; 78-79).

As part of his educational agenda, 'Abduh proposed the unification of education in Egypt through the development of Dār al-'Ulūm so that it could, in the future, replace al-Azhar. Besides those ideas, he also planned to found an Egyptian University as a supplement to al-Azhar. However, this plan was not realized until after he died. Through the efforts of his pupils, such as Sa'ad Zaghlul, Qasim Amin, Hifni Nasif, Lutfi al-Sayyid and other 
followers, his project was brought to fruition by the establishment of the Egyptian University in 1908 (Adams, 1968).

\section{Indonesian Education in the Time of the Establishment of the Muhammadiyah}

'Abduh's thought and ideas then spread to Muslims outside of Egypt. As far away as Indonesia, in Southeast Asia, 'Abduh's writings were read and studied with much enthusiasm and interest by young and earnest Indonesians. Among these, was Kyai Haji Ahmad Dahlan (1868-1923), who was soon to become the founder of the Muhammadiyah, an Islamic mission organization and movement that introduced ideas and reforms in Indonesia that echo many of the ideas of 'Abduh (for detailed discussion of Dahlan's biography see. Salam, 1968; Hadikusuma, 1972; Salam, 1965). The Muhammadiyah, founded by him and a group of his close friends, was formally established on November 18, 1912, coinciding with Dhu al-Hijjah 8, 1330, at Kauman, Yogyakarta, of which Ahmad Dahlan acted as the first Chairman (for detailed discussion about the history and ideology of the Muhammadiyyah, see.Kutoyo, 1998; Damami, 2000; Nashir, 2001; Pasha \& Darban, 2002; Sairin, 1995; Fuad, 2002, Wanandi, 2002; Nakamura, 1980; Nakamura, 2012; Syamsuddin, 1990; Yusuf et al., 1990) . The system of education in Indonesia in the time of the establishment of the Muhammadiyah was almost the same as that which Muhammad 'Abduh had encountered in Egypt. There were two different systems of education, that werereligious institutions and secular schools established by the Dutch. The only difference is that there was no separate formal higher education in Indonesia, neither religious like that of al-Azhar nor secular like that established by the Khedives of Egypt. The religious educational institutions, which were comparable to the kuttāb in Egypt, had been established by the Muslim scholars who spread Islam in Indonesia. Those institutions were called pesantren (Islamic boarding school), which in some parts of Indonesia is also called pondok(see e.gAzra et al., 2007; Lukens-Bull, 2001; 
Pohl, 2006). These were the religious educational institutions in which higher education was offered along with other levels of education. Primary or elementary religious education was provided at home with the members of a child's family, at the mosque, at the langgar, or at the home of a religious teacher. In these places, children learned how to read the Qur'an and perform some other obligatory practices such as $w u d \underline{u} u^{\prime}$ (ablution), șalāh (prayer) and saum (fasting) while being introduced at the same time to some basic tenets of theology; i.e., the twenty attributes of God. This preliminary teaching was usually given after Maghrīb (prayer after sunset) or after Subuh (prayer before sunrise), with the students seated on the floor around the teacher. The teacher read the Qur'an word by word and the student repeated the teaher's reading. The following day, the student read the same portion of the Qur'an which had been read by his teacher the day before. This instruction was given individually, and the students were not organized into classes. Each student's progress would be assessed individually by the teacher. It is worth mentioning that before the students learned how to read the Qur'an, they studied huruf Hijā'iyyah (Arabic alphabet) with the book which was named Qāiidah Baghdādiyyah such asalif, $b \bar{a}, t \bar{a}, t h \bar{a}$, etc. and then the Arabic punctuation marks likefathah, kasrah and d ammah, as well as sukūn and tashdìd. They did not learn how to write (Yunus, 1979).

If the student wanted to pursue the study of the religious sciences, he could go to pesantren. The teacher in this institution was named kyai and the student was named santri, and they lived on one campus. It was a compound usually located around a mosque in which the santris were to sleep, cook for themselves, and, above all, obtain their education and religious training. The reputation of a pesantren and the standard of education offered there depended very much on the personality and intellectual achievement of the kyai who directed it. The education provided in it, at least up to the early twentieth century, consisted exclusively of the study of religious subjects and Arabic such as fiqh, uṣul al-fiqh, hadīth, muṣtalah al- 
hadīth, tafsīr of the Qur'an, tauhīd, akhlāq, tașawwuf, Islamic history, falāq, as well as Arabic, covering naḥw, șarf, balāghah, 'arūẹ and adāb. Usually every pesantren specialized in the study of particular standard works. For instance, pesantren Tremas was well-known for its kyais who were experts in Arabic grammar; Tebuireng with its kyai, Hasyim Asy`ari, was well-known as an expert on hadīth; while Jampes was well-known for its kyais who were experts on tasawwuf (Dhofier, 1980). The teaching methods in the pesantren were sorogan and bandongan or weton. Both methods emphasized memorizing, rather than enhancing intellectual development of the students; the sorogan was a personal method in which a teacher gave lessons to the student individually. The teacher read passages from Arabic texts and translated them word by word into the local language, and then the student was required to imitate those passages well. The student, in return, repeated and translated them as correctly as possible, and he would only be able to continue further if he had mastered the previous lesson (Jones, 1983). This method was used for elementary students; and for intermediate and advanced students, the method used was bandongan or weton. It was a system in which a group of students listened to a teacher who read, translated and explained the Arabic texts. Each student had his own copy of the text and wrote notes on particular words which he did not know. In this system, the students were not required to imitate what the teacher read, and there was no checking on whether they understood or not. There were no classes in the pesantren and there was no formal means of assessing a student. A student's progress depended solely upon his own devotion and industry. His knowledge was judged by the number of books he had read and the kyais under whom he had studied. The more able students who completed the pesantren courses usually returned home to their villages where they would establish a new pesantren; while those who dropped out before they reached advanced studies were advised by the kyai to be religious teachers at langgar or their own home. It is true that the methods of teaching in the pesantren produced some results, but only very slowly. It normally took a student ten to fifteen years 
to acquire sufficient knowledge from those traditional methods of instruction.

Besides these Muslim educational institutions, in 1866, the Dutch began to establish schools with secular system. This was the result of the influence of some progressives who felt that the indigenous peoples should be educated because of the need for a labor force to perform junior clerical duties in businesses and plantations (Soebardi \& Woodcroft-Lee, 1982; Israeli, 1982). The Dutch educational system, of course, was entirely different from the pesantren system and did not spread widely among the Indonesians until the introduction of the so called "ethical policy" in the end of the nineteenth century (Furnivall, 1944; 231). In 1900, out of a native population in Java of nearly 30 million there were only 1,615 people who went to school. When the ethical policy gained in favor of education began to make new headway. Thus, in 1905 there were 3,935 Indonesians against 19,049 Europeans; and 3,710 Indonesians against 21,731 Europeans in 1910. The curriculum in those institutions was identical with that in Dutch schools.

"A comprehensive curriculum is a characteristic feature of Dutch education, and the course in these MULO (Meer Uitgebreid Lager Onderwijs/junior high school), schools is practically identical with that in the Mulo classes of the European schools; the compulsory subjects are Dutch, English, German, General History, Science, Mathematics and Drawing, and the course differs from that of Dutch schools mainly in that of French is optional instead of compulsory." (Furnivall, 1944; 364-366).

Besides being oriented towards the interests of the colonial government, as mentioned above, this education also was intellectualistic and individualistic; it lacked a distinct moral foundation. The upper stratum of Indonesian society soon came under the influence of Western culture; and a certain number of its characteristics, such as individualism, rationalism and naturalism, gained a hold on the Indonesians, especially those who studied in the Dutch schools. Thus, at the time when Indonesian Islam was not yet wholly purified from indigenous unorthodox practices, the Dutch educated intelligentsia began, under the influence of the 
abovementioned Western culture, to regard that Islam as an oldfashioned religion, an obstacle to progress. Reinforcing this attitude was the marginal position which Islam occupied in the life of the Muslim masses and the inability of the religious schools to produce scholars of the worldly sciences on a par with the graduates of the Dutch colonial schools (Ali, 1985).

\section{Early Steps in Muhammadiyah's Programs on Educational Reform}

Witnessing that the educational system had split in two different directions, Dahlan, the founder of the Muhammadiyah, like 'Abduh in Egypt, was worried about the coming generations of Muslims. This is among the factors which led Dahlan to establish the movement, one objective of which was to reform Muslim education (see further in Ali, 1957). The educational reform conducted by the Muhammadiyah sought both to articulate an educational ideal and to provide a methodology by which to translate it into practice. Amir Hamzah Wirjosukarto, in Pembaharuan Pendidikan dan Pengajaran Islam jang Diselenggarakan oleh Perguruan Muhammadijah published by Pembaharuan Pendidikan/Pengadjaran Islam in 1962, as quoted in Jainuri (1981: 65) stated that that ideal was the production of Muslims who were good in character, knowledgeable in religion, broad in insight, fully conversant with the secular sciences (from which later on emerged the concept of the person who was "intellectual- 'alim" and "alim-intellect"), and willing to strive for progress in their society. The methodology was intended to bring about educational practice which would make this ideal person into a reality. At the time of the movement's foundation, the problems which Muslims of Indonesia face in the realm of education were the backwardness of the Islamic institutions, or pesantrens which were unable to meet the needs of moderndevelopment due to an isolationist policy and an obsolete educational method; and, the emergence of secular schools run by the Dutch-colonial regime, 
which threatened the spiritual life of Muslim youths because they ignored their religion and the civilization of their nation.

The Muhammadiyah's first effort in the field of education was to counter the poor quality and narrow emphasis of the pesantren institutions by establishing madrasahs (religious schools) that provided quality instruction both in religion and in secular subjects taught in Western schools, such as mathematics, natural sciences, history and humanities. Unlike the pesantren institutions, which stressed on memorization, these madrasahs stressed on understanding. The ratio of religious to secular subjects in the madrasahs varied; some of them had a ratio of 70:30; some had 60:40 and the others had 50:50 for religious and secular subjects, respectively. These madrasahs differed from the pesantren in many ways. Madrasah students attended lessons in a classroom where they sat at desks; their work was evaluated through formal examinations, and they were given individual marks. Thus, the student was able to move from grade to grade until he completed his education, whereupon he was awarded a certificate. Another significant innovation was the opportunity for girls to obtain education, even permitting them to study alongside male students in the same class. This model of madrasah was extended into the realm of secondary education with the establishment in 1920 of the Pondok Muhammadiyah, a five-year school system offering both religious and secular subjects. Later on, in 1924 this institution was modified into Kweekschool Muhammadiyah Putri (and then was changed to be Madrasah Mu'allimat Muhammadiyah) and Kweekschool Muhammadiyah Putra (and then was changed to be Madrasah Mu`allimin Muhammadiyah) for female and male, respectively. For the Pondok Muhammadiyah, the movement was able to recruit and hire a number of qualified teachers to teach secular subjects, while the Muhammadiyah's leaders, such as Kyai Haji Ahmad Dahlan, Kyai Haji Hadjid, Kyai Haji Ibrahim and Kyai Haji Hanad, were to offer religious subjects (Jainuri, 1982). At about the same time, the movement conducted remedial religious 
courses for those who did not study in the Muhammadiyah's madrasahs (Wirjosukarto, as quoted in Jainuri, 1982: 73). The Muhammadiyah's second effort in education was to establish, as an alternative to the madrasah, a second type of school which followed the Western system of education and adopted the Dutch language. This reveals the movement's recognition of the advantages of Western methods and techniques. In effect, this type of school was a counterpart of the Dutch government school in Indonesia. The movement founded HIS (Hollands Inlandse School/ Dutch-speaking native elementary school) in 1926 and then Schakelschool (Dutch language elementary school), MULO (Meer Uitgebreid Lager Onderwijs/junior high school), HIK (Hollandse Inlandse Kweekschool/training school for native teachers) and AMS (Algemene Middelbare School/senior high school). The only difference from the Dutch schools was that religion was taught as a compulsory subject and that the students were subjected to religious disclipinary regulations. Religious courses of instruction in those institutions constituted about ten to fifteen percent of the entire curriculum (Jainuri, 1982). The Muhammadiyah thus maintained a dual educational system, reflecting the original dichotomy of the pesantren and Dutch systems but integrating religious and secular sciences in both systems. There existed, on the one hand, the madrasahs, and on the other hand, schools which were similar to those established by the Dutch. In the madrasahs, religious subjects predominated; while in the Muhammadiyah's counterpart of the Dutch secular schools, secular knowledge predominated with religious knowledge nonetheless playing an important role. After the Indonesian independence, the Muhammadiyah transformed its dual educational system into a public school system supervised by ministries of the government. As a result, there are in Indonesia today two kinds of educational systems.One isthe madrasah system controlled by the Ministry of Religious Affairs,andthe other isthe secular system controlled by the Ministry of Education and Culture. The levels of the madrasah system are Bustanul Athfal (Kindergarten), Madrasah Ibtida'iyah 
(Elementary School) grades 1-6, Madrasah Tsanawiyah (Junior High School) for grades 7-9,Madrasah 'Aliyah (Senior High School) for grades 1012, and the Islamic Insitute, which includes undergraduate and graduate levels. The secular system covers Taman Kanak-Kanak (Kindergarten),Sekolah Dasar (Elementary School) for grades 1-6,Sekolah Lanjutan Pertama (Junior High School) for grades 7-9, Sekolah Lanjutan Atas (Senior High School) for grades 10-12, and college and university. It is worth mentioning that in the secular system, the religious instruction is given in all levels from kindergarten to university in accordance with the student's religion. The Muhammadiyah adopted both systems run by the government, the only difference being that the Muhammadiyah's schools provide religious instruction more than that in government schools, and all students must receive Islamic instruction. In the government schools, religious instruction is allocated for two hours a week, while in the Muhammadiyah's schools, six hours a week are allocated for it(Puar, 1989).

In 1955, for the first time, the Muhammadiyah established a university comprising a Faculty of Law and Philosophy at Padang Panjang, Sumatra. Two years later, in 1957, the movement established a College of Education at Jakarta; and in the following year, the College of Education at Surakarta and Akademi Tabligh (Academy of Islamic Propaganda) at Yogyakarta were established (Yunus, 1979). The movement continued to establish more institutions of higher education, and according to the report in the Muktamar (Congress) of Muhammadiyah in Surakarta 1985, the movement had fifteen universities consisting of ninety-two faculties, five institutes of education consisting of fourteen faculties, three institutes of Islamic studies consisting of six faculties, thirteen colleges of education, one college of business, and one academy of banking. Besides these, the Muhammadiyah managed more than 12,400 madrasahs and schools from kindergarten through senior high school throughout the country(Puar, 1989). 


\section{Tracing ‘Abduh's Influence on the Muhammadiyah Educational Reform}

This section attempts to compare Muhammad 'Abduh's ideas and programs relating to educational reform with those introduced and implemented by the Muhammadiyah movement in Indonesia. This discussion will assess how far the ideas and programs of 'Abduh influence those of the movement. From the previous section, some similarities in ideas and programs between the educational reform of 'Abduh and that of the Muhammadiyah were seen. First, there is a similarity in the ideal or purpose of education. Both 'Abduh and the founder of the Muhammadiyah pinned their hopes for the survival of Islam and the progress of the community on the improvement of education. They considered that education was key to socio-religious reform, that the only way to achieve prosperity in a nation is through the general extension of education. The purpose of education, according to both 'Abduh and the Muhammadiyah, is to generate good Muslims who have a solid understanding of both the religious and secular sciences which will enable them to achieve happiness in this world as well as in the hereafter. Both also believe that Muslims must be willing to struggle for their society. These convictions were prompted by the fact that the educational systems in Egypt and in Indonesia were divided between two different directions, that were the Muslim traditional institution and the secular school. These two types of education were segregated from each other, neither was satisfactory by itself the Muslim institution (in Egypt called al-kuttāb with al-Azhar at their apex, and in Indonesia called pesantren) suffered from stagnation and slavish imitation. This institution taught religious sciences in a certain sterile way and ignored the sciences which were necessary for living in the modernworld. They used the traditional methods of teaching which required students to listen, read and memorize without encouraging them in the direction of critical thought or of taking an interest in self-education outside or beyond the institution. On the other side, secular schools established by the government 
taught no religious sciences (some schools in Egypt taught those sciences but in a very limited portion). Consequently, these two systems of education produced two different educated classes, each with a spirit of its own. One was the traditional Islamic spirit which resisted all change. The other was the spirit of the younger generation who accepted all change and all the ideas of modernEurope and many of whom became indifferent towards religion. They were very different in almost every department of social and intellectual activity as well as in their way of thinking.

Realizing this condition, both 'Abduh and the founder of the Muhammadiyah were worried about the coming generations, convinced that traditional education had failed to produce Muslims who could solve the complex modern problems, while the more recently introduced secular education had failed to train the souls. Education, according to the Muslim reformers, should be able to train both minds and souls, to promote both intellectual and spiritual growth. Intellectual growth was mandated by Islam, which not only allowed Muslims to study sciences which were useful for life in this world but made it an obligation for Muslims to study them. As for spiritual growth, religion is deemed essential; only religion could train the souls. The idea of integrating religious and secular sciences within a single educational program was given its classical expression by al-Ghazali, a Muslim philosopher who died in the twelfth century. He grouped all the branches of knowledge into 'ulūm shar'iyyah (religious sciences) and 'ulūm ghayr shar'iyyah (non-religious sciences). Religious sciences are branches of knowledge which have their source in prophetic revelation. Thus, reason as such is not their source, as is the case with arithmetic; and empirical observation is not their source, as is the case with science; finally, aural experience is not their source, as is the case with linguistic science. As for non-religious sciences, some are laudable, some are reprehensible, and some are permissible. The laudable sciencies are those which are related to the interests of worldly matters such as medical science and arithmetic. The reprehensible sciences include such things 
as knowledge of black magic and talismans. Examples of the permissible sciences are economics and history (Ghazali, 1967: 27-28). 'Abduh as much as the founder of the Muhammadiyah believed that both kinds of sciences should be taught in the educational institutions, whether in religious (i.e. madrasah type) or secular schools. Therefore, in their program of educational reform, they endeavored to introduce non-religious sciences into the religious institutions. At the same time, they also attempted to introduce religious sciences in the secular schools.

In terms of programs, there are some similarities between 'Abduh and the Muhammadiyah reformers. Both considered that the Islamic educational institutions were unable to meet the needs of moderndevelopment due to their isolationist policy and traditional, obsolete educational methods. 'Abduh endeavored to modernize such religious institutions as al-Azhar by introducing new subjects or courses which fell under the heading of secular sciences, and also employing new teaching method which emphasized comprehension rather than memorization. The Muhammadiyah reformers acted in the same way as 'Abduh by establishing madrasahs (religious schools) which provided secular subjects along with religious ones and by using new teaching methods stressing understanding rather than learning by heart. 'Abduh and the Muhammadiyah reformers were convinced that secular sciences were needed by the Muslims along with the religious ones. They felt that the Islamic system of teaching must adopt the same scientific empiricism in worldly matters which the Muslims themselves had once developed but had forgotten during subsequent centuries. In the Abbasid period, when the rulers supported the development of knowledge by building mosques and establishing schools, Islamic civilization reached its peak. Major contributions were made in many fields such as medicine, mathematics, algebra, geometry, astronomy, science, literature, philosophy, art and architecture. The world recognizes the greatness of such figures as al-Razi (d. 925), al-Farabi (d. 950), Ibn Sina (d. 1037), al-Biruni (d. 1048), al-Ghazali (d. 1111) and 
Ibn Rushd (d. 1198) (Esposito, 1988; Wickens, 1976). 'Abduh found that the secular schools were aimed at provide training which would serve government interests, ignoring religion and character building. Therefore, he encouraged the government to base these educational institutions on Islam. Unless this was done, their products would become worse because their general knowledge and demeanor were not based on the principles of their religion, and thus there would be no refinement of their souls. The Muhammadiyah reformers also faced the same problem in Indonesia. In the secular schools administered by the Dutch colonial government, the Dutch had promoted educational programs which served their own colonial interests. To solve this problem, the Muhammadiyah established its own brand of secular schools which were similar to the Dutch system, except that the Muhammadiyah's schools provided religious instructions. These are the similarities among ideas and programs between 'Abduh and the Muhammadiyah reformers. The only slight difference between 'Abduh's programs and those of the Muhammadiyah reformers is that 'Abduh put greater emphasis on the reform of higher education rather than education at all levels. This fact is underscored by his endeavor to reform al-Azhar and Dār al-'Ulūm as well as by his idea of establishing an Egyptian University. In contrast, the Muhammadiyah emphasized all levels of education. It established the educational institutions from the kindergarten level up to the university level. This difference follows from several reasons, among them, the educational condition itself. Egypt was the first country to have a higher Muslim education; i.e., al-Azhar. People from many Muslim countries came to study in al-Azhar, and so it was an international center of Muslim education. 'Abduh believed that if al-Azhar was reformed, Islam would be reformed through the students who came to learn there. Those who were acquainted with Islamic reform could promote it among the masses in their home countries. Therefore, al-Azhar played an important role in reforming Islam throughout the entire Muslim world. 
The situation of education in Indonesia was very different from that of Egypt. Until the second decade of the twentieth century, the time of the establishment of the Muhammadiyah, Indonesia had no formal higher educational institutions, religious or secular. Therefore, it is understandable that the Muhammadiyah reformers did not emphasize its programs on higher education; rather, the reformers concentrated on general education. From the indisputable similarities which have been noted above, one is tempted to conclude that 'Abduh's ideas and programs had influenced those of the Muhammadiyah, particularly in the matter of educational reform. 'Abduh was alive and propagated his ideas well before the Muhammadiyah was established. 'Abduh was an able person who presented his ideas through writings, lectures and other activities. He wrote articles, books, as well as letters to the Shaykh alIslam in Constantinople and the Governor of Beirut. He submitted a proposal to the Khedive, and disseminated his ideas through lectures so that he became one of the bestknown men in Egypt, as well as in the entire Muslim world. On the contrary, Dahlan, the founder of the Muhammadiyah movement, never wrote any book. His ideas, however, may be deciphered from the various programs about which he spoke in public speeches and which he implemented through the Muhammadiyah. It seems clear that his ideas for reforming the educational system were inspired by the books and journals written by the Muslim reformists. It is well documented that he read the writings of the Muslim reformers, particularly 'Abduh and Rashid Rida (especially al-Manār). In the matter of education, Rida was influenced very much by 'Abduh; his ideas and programs were almost the same as those of 'Abduh. The educational reform programs of the Muhammadiyah were founded on ideas which were undeniably similar to the ideas of 'Abduh. What 'Abduh had advocated in his various works in the way of a reform of education which would prepare Muslims to take greater responsibility in running their country and to participate in the modern world coincided exactly with the goals that the Muhammadiyah was working to achieve it 
in Indonesia. This suggests that the Muhammadiyah's programs were to a significant extent influenced by 'Abduh. However, the precise extent of this influence is somewhat speculative. The evidence which points to some degree of influence -a degree that may be pronounced significant- is certainly there. But we must also take into account the substantial evidence which indicates that the Muhammadiyah reformers exercised their own share of ijtihād.Similarity is, of course, not an absolute proof of influence. However, when combined with chronological succession and with known channels of communication and contact, it becomes an indicator of probable influence, however unquantifiable that influence might be. As Malcolm H. Kerr (1966) has argued, the true influence of 'Abduh as a Muslim reformer on those who had read and studied him occurred within a complex historical stream. He was indeed the first 'to fling open the doors and expose a musty tradition to fresh currents,' although the Muslim reformers or movements who came after him were to receive other influences as well 'Abduh's influence on the Muhammadiyah must be seen in this same light. It is an oversimplication to say that the Muhammadiyah programs in the matter of educational reform were nothing but the outcome of the influence of 'Abduh since there is no absolute proof of this. For this reason, the authors conclude that the educational reform of the Muhammadiyah in Indonesia shows traces of a probable but unquantifiable influence of Muhammad 'Abduh and that this reform is certainly, at the very least, a reflection of 'Abduh's pervasive influence throughout the larger world of Islam.

\section{Conclusion}

Islamic reform emerged as a response to the decline of Muslim communities. The Muslim reformers, such as al-Sayyid Jamal al-Din al-Afghani, Muhammad 'Abduh, and Muhammad Rashid Rida, revealed that the decline was caused by the intellectual anarchy among the Muslim society; they regarded the door of ijtihād as closed, accepted the idea of taqlīd, and tolerated 
the practice of bid'ah. Such reform appeared in the late nineteeth century, and one of its most prominent advocates was Muhammad 'Abduh from Egypt. Among 'Abduh's ideas on Islamic reform is the call for Muslims to return to the Qur'an and the hadith; the belief that the door of ijtihād is still open, and the rejection the idea of taqlīd and bid'ah. He believed that religion and reason are complementary and that there is no inherent contradiction between religion and science. He was a thinker who attempted to reconcile Islam with the attainments of modern science and adapted it to the requirements of modern civilization. He wrote a number of books and articles embracing a variety of subjects. His ideas also were spread by his most prominent disciple, Muhammad Rashid Rida, through a journal named al-Manār. 'Abduh's writings and the journal were read by many Muslims in areas as distant as Indonesia. One of 'Abduh's most important efforts was in the area of Muslim educational reform. He regarded education as an essential means for social reform and pinned his hopes for the survival of Islam and the progress of the Muslim community on the improvement of Islamic education. Education, according to him, is not only for training minds, but also for the refinement of souls. The former calls for study of the secular sciences needed for living in the modern age, but for the latter, religion is essential, because the science which will refine the soul is the science which disciplines it and such a discipline exists only in religion. The aim of education is to prepare people to achieve happiness both in this world and the hereafter and to strive in this world for the good of their society. Hence, both the secular and religious sciences are important for the well-being of Muslims. 'Abduh witnessed the split of the educational system in Egypt into two divergent segments, that were religious educational institutions and secular schools neither of which was satisfactory by itself. The former taught only religious sciences, ignoring the secular ones needed by people living in modern times, while the latter did not introduce sciences required for the refinement of souls. 'Abduh's reforms for the religious institutions aimed at introducing secular 
sciences and changing the method of teaching. As for the secular schools, 'Abduh endeavored to introduce religious instruction for the training of souls.

The Muhammadiyah movement in Indonesia, which was established by Kyai Haji Ahmad Dahlan on November 18, 1912, had some similarities with 'Abduh's ideas and programs. The movement endeavored to introduce secular sciences into the curriculum of the religious school by establishing a new type of religious school named madrasah and by employing new method of teaching. This system was intended to replace the Muslim traditional institution called pesantren. At the same time, the movement introduced religious instructions into the secular schools established by the Dutch.Italso established its own "secular" schools in which secular sciences predominated over religious sciences with the latter still playing a vital role. Because of these similarities, some regard the Muhammadiyah's programs as being influenced by the ideas of 'Abduh. This opinion enjoys some credibility since after 'Abduh's death in 1905 his ideas were disseminated widely through his books and al-Manār journals. The founder of the Muhammadiyah read 'Abduh's books and those journals. Thus, it is not mistaken to suppose that 'Abduh's ideas had an appreciable influence on the Muhammadiyah movement in this arena. However, there is no documented evidence indicating with absolute certainty a direct influence of 'Abduh on the Muhammadiyah in the sense of a straightforward cause-andeffect relationship. For this reason, the author would not go so far as to claim that the Muhammadiyah's programs of educational reform were simply outworkings in the Indonesian environment of 'Abduh's ideas. We do conclude, however, that its programs bear the unmistakable stamp of 'Abduh's wider influence on the Muslims reformers in Indonesia in general. 


\section{REFERENCES}

Adams, C.C.(1968). Islam and Modernism in Egypt: A Study of the Modern Movement Inaugurated by Muhammad Abduh. New York: Russell \& Russell.

Ahmed, J. M. (1960). Intellectual Origins of Egyptian Nationalism. New York: Oxford University Press.

Alatas, S. F. (1985). Notes on various theories regarding the Islamization of the Malay archipelago. The Muslim World, 75(3-4), 162-175.

Al-`Adawi, I. A. (n.d). Rashid Rida: al-Imam al-Mujahid. Egypt: alMu'assasah al-Misriyyah al-'Ammah.

Al-Ghazali, M. (1967). Ihya' 'Ulūm al-Din, (Vol. 1).Cairo: Mu'assasat al-Halabi wa-Shurakah li al-Nashr wa al-Tauzi`.

Ali, A. M. (1957). Bibliographical Study of the Muhammadijah Movement in Indonesia. MA Thesis, McGill University, Montreal, Canada (unpublished).

Ali, A. M. (1985). Interpretasi Amalan Muhammadiyah (Interpretation of Muhammadiyah's Work). Jakarta: Harapan Melati.

Amin, U. (1965). Ra'id al-Fikr al-Misri: al-Imam Muhammad Abduh, (2nd ed). Cairo: Maktabat al-Anjalu al-Misriyyah.

Amin, U.(1953). Muhammad 'Abduh,translated from Arabic by Charles Wendell. Washington D.C.: American Council of Learned Societies.

Aroian, L. A. (1983). The Nationalization of Arabic and Islamic Education: Dār al- 'Ulūm and al-Azhar.Cairo: The American University in Cairo.

Azra, A. (2004). The Origins of Islamic Reformism in Southeast Asia: Networks of Malay-Indonesian and Middle Eastern 'Ulamā' 
in the Seventeenth and Eighteenth Centuries. Honolulu: University of Hawaii Press.

Azra, A., Afrianty, A.,\& Hefner, R. W. (2007). Pesantren and madrasa: Muslim schools and national ideals in Indonesia. InRobert W.Hefnerand Muhammad Qasim Zaman (Eds.),Schooling Islam: The culture and politics of modern Muslim education(pp. 172-198). Princeton University Press.

Badawi., M. A. Z. (1978). The Reformers of Egypt. London: Croom Helm.

Damami, M. (2000). Akar Gerakan Muhammadiyah. Yogyakarta: Fajar Pustaka Baru.

Dhofier, Z. (1980). The Pesantren Tradition: A Study of the Role of the Kyai in the Maintenance of the Traditional Ideology of Islam in Java. Canberra: The Australian National University Dissertation.

Dodge, B. (1961). Al-Azhar: A Millennium of Muslim Learning. Washington, D.C.: The Middle East Institute.

Esposito, J. L. (1988). Islam the Straight Path. New York: Oxford University Press.

Federspiel, H. M. (1970). The Muhammadijah: A Study of an Orthodox Islamic Movement in Indonesia. Indonesia, (10), 57-79.

Fuad, M. (2002). Civil Society in Indonesia: The Potential and Limits of Muhammadiyah. Sojourn: Journal of Social Issues in Southeast Asia, 133-163.

Furnivall, J. S. (1944). Netherlands India: A Study of Plural Economy. New York: The Macmillan Company.

Hadikusuma, D. (1973). Aliran pembaharuan Islam dari Jamaluddin al-Afghani sampai KHA Dahlan.Yogyakarta: Persatuan.

Heyworth-Dunne, J. (1968).An Introduction to the History of Education in Modern Egypt.London: Frank Cass \& Co. Ltd. 
Hourani, A. (1955). Arabic Thought in the Liberal Age: 1798-1939. London: Oxford University Press.

Houtsma,M.TH., Wensinck, A. J., Gibb,H. A. R., Heffening, W. \& Levi-Provencal, E. (1987). First Encyclopedia of Islam 19131936, (Vol VII ed). New York: EJ Brill.

Imarah, M.(1972). al-A'mal al-Kamilah li al-Imam Muhammad Abduh,(Vol. 3). Beirut: al-Muassasah al-`Arabiyyah li alDirasat wa al-Nashr.

Israeli, R. (1982). The Crescent in the East: Islam in Asia Minor, (1st ed). London: Curzon Press.

Jainuri, A. (1981).Muhammadiyah: Gerakan Reformasi Islam di Jawa Pada Awal Abad Kedua Puluh (Muhammadiyah: An Islamic Reform Movement in Java in the Early of the Twentieth Century), (1st ed.). Surabaya: PT Bina Emu.

Jones, S. (1983). Arabic instruction and literacy in Javanese Muslim schools.International Journal of the Sociology of Language, 1983(42), 83-94.

Kamal, M., Yusuf, C.,\& Sholeh, A. R. (1988). Muhammadiyah sebagai Gerakan Islam (Muhammadiyah as Islamic Movement), (6th ed.). Yogyakarta: Penerbit Persatuan.

Kerr, M. H. (1966). Islamic Reform: The Political and Legal Theories of Muhammad 'Abduh and Rashid Rida. Berkeley: University of California Press.

Kutoyo, S. (1998). Kiai Haji Ahmad Dahlan dan Persyarikatan Muhammadiyah. Jakarta: Balai Pustaka.

Lukens-Bull, R. A. (2001). Two sides of the same coin: Modernity and tradition in Islamic education in Indonesia. Anthropology \& Education Quarterly, 32(3), 350-372.

Landon, K. P. (1947). Southeast Asia: Crossroad of Religions. Chicago: The University of Chicago Press. 
Lubis, A. (1993). Pemikiran Muhammadiyah dan Muhammad Abduh: Suatu Perbandingan, Jakarta: Bulan Bintang.

Madmarn, H. (1990).Traditional Muslim Institution in Southern Thailand: A Critical Study of Islamic Education and Arabic Influence in the Pondok and Madrasah Systems of Pattani (Dissertation,University of Utah).

Nakamura, M. (1980). The Reformist Ideology of Muhammadiyah. In Fox, J. J. (Ed.), Indonesia: The Making of a Culture. (pp. 273-86).Research School of Pacific Studies, Australian National University

Nakamura, M. (2012). The Crescent Arises Over the Banyan Tree: A Study of the Muhammadiyah Movement in a Central Javanese Town, c. 1910-2010. Singapore: Institute of Southeast Asian Studies.

Nashir, H. (2001). Ideologi Gerakan Muhammadiyah (Ideology of the Muhammadiyah Movement). Yogyakarta: Suara Muhammadiyah.

Noer, D. (1973). The Modernist Muslim Movement in Indonesia 1900-1942. Singapore: Oxford University Press.

Palmier, L. H. (1954). Modern Islam in Indonesia: The Muhammadiyah after Independence. Pacific Affairs 27 (3), 255-263

Pasha, M. K., \& Darban, A. A. (2002). Muhammadiyah sebagai Gerakan Islam dalam Perspektif Historis dan Ideologis (Muhammadiyah as an Islamic Movement in Historical and Ideological Perspectives.). Yogyakarta: LPPI Universitas Muhammadiyah Yogyakarta.

Peacock, J. L. (1978). Purifying the faith: the Muhammadijah movement in Indonesian Islam, (Vol. 8). San Fransisco: Benjamin-Cummings Publishing Company. 
Pohl, F. (2006). Islamic education and civil society: Reflections on the pesantren tradition in contemporary Indonesia. Comparative Education Review,50(3), 389-409.

Puar, Y.A. (1989). Perjuangan dan Pengabdian Muhammadiyah (The Muhammadiyah Struggle and Service). Jakarta: Pustaka Antara.

Rida, M. R. (1327 AH). Al-Manar, (Vol. 1). Cairo: Matba'at alManār.

Rida, M. R.(1350 AH). Tarikh al-Ustadh al-Imam al-Shaykh Muhammad 'Abduh, (Vol. 1). Cairo: Matba'at al-Manār.

Rida, M. R.(1344 AH). Tarikh al-Ustadh al-Imam al-Shaykh Muhammad 'Abduh, (Vol. 2). Cairo: Matba'at al-Manār.

Rida, M. R.(1324 AH).Tarikh al- Ustadh al-Imam al-Shaykh Muhammad Abduh, (Vol. 3). Cairo: Matba'at al-Manār.

Rida, M. R. (1329 AH).Al-Manār, (Vol.14). Cairo: Matba`at alManār.

Sairin, W. (1995). Gerakan Pembaruan Muhammadiyah. Jakarta: Pustaka Sinar Harapan.

Salam, J. (1968). Riwajat Hidup KHA Dahlan: Amal dan Perdjoangannya (The Biography of KHA Dahlan: His Work and Struggle). Jakarta: Depot Pengadjaran Muhammadijah.

Salam, S. (1965). Muhammadijah dan Kebangunan Islam di Indonesia (Muhammadiyah and Islamic Resurgence in Indonesia). Jakarta: N.V Mega.

Saleh, F. (2001). Modern Trends in Islamic Theological Discourse in 20th Century Indonesia: a Critical Survey (Vol. 79). Leiden: Brill.

Soebardi, S. and Woodcroft-Lee. C. R.(1982). Islam in Indonesia. In Raphaeli Israeli (Ed.), The Crescent in the East: Islam in Asia Major. London: Curzon Press Ltd. 
Syamsuddin, M. D. (1990). Muhammadiyah Kini dan Esok. Jakarta: Pustaka Panjimas.

The Department of Information of the Republic of Indonesia. (n.d). Indonesia at a Glance.Jakarta: The Department of Information of the Republic of Indonesia

Susilo, S., \& Syato, I. (2016). Common identity framework of cultural knowledge and practices of Javanese Islam. Indonesian Journal of Islam and Muslim Societies, 6(2), 161-184.

Wanandi, J. (2002). Islam in Indonesia: Its history, Development and Future Challenges. Asia Pacific Review, 9(2), 104-112.

Wickens, G. M. (1976). The Middle East as a World Centre of Science and Medicine. In R.M. Savory, Introduction to Islamic Civilization. New York: Cambridge University Press.

Yunus, M. (1979). Sejarah Pendidikan Islam di Indonesia (The History of Islamic Education in Indonesia). Jakarta: Mutiara.

Yusuf, M. Y, Ridjal, S.,\& Abbas, A. (1985). Cita dan Citra Muhammadiyah (Idea and Scenery of Muhammadiyah). Jakarta: Pustaka Panjimas. 
|Muslich Shabir dan Sulistiyono Susilo 